\title{
KANTTEKENINGE BY KARL BARTH SE
}

\author{
KERKREGBESKOUING
}

Dr. C. J. Smit.

\section{Verantwoording (of verontskuldiging?)}

Vanweë publikasieruimte kan hier nie omvattend op Barth se kerkregbeskouing ingegaan word nie, derhalwe verontskuldig ek my met 'n klompie kanttekeninge. Hopelik gee dit tóg 'n duidelike beeld van 'n behartigenswaardige kerkregbeskouing weer.

Op 10 Mei, presies ' $n$ eeu gelede, is Karl Barth gebore. As die bekendste, waarskynlik die invloedrykste teoloog van hierdie eeu, het hy nooit as 'n kerkregtelike gepretendeer nie. As gedeë (en terdeë omstrede!) dogmatikus het hy egter die grondslae vir die kerkreg uit 'n dogmatiese hoek behandel. Ten minste op so 'n wyse dat dit sonder meer die moeite loon om daarop in te gaan.

\section{Kanttekeninge}

1. Barth is eksplisiet oor die oorsprong en die aard van die reg en orde in die gemeente. Die reg en orde fundeer in Jesus Christus as Hoof van sy liggaam. Hý is die primêr handelende Subjek in die gemeente: 'n waarheid wat nie slegs in die kerk se belydenisskrifte verskuil moet word nie, maar wat in die praktiese orde van die gemeente tot uitdrukking moet kom'.

2. Die konstituerende grondslag ("Ordnungsprinzip") van die gemeente is die verhouding van Jesus Christus en die communio sanctomum met mekaar. Hierdie verhouding is derhalwe ook die "Grundrecht" van waaruit die kerkreg, as die reg wat in die kerk ontstaan en vir die kerk geld, ontplooi word. Derhalwe is die kerkreg nie 'n aangeleentheid van sekondêre betekenis vir die kerk nie ${ }^{2}$.

3 . In sy beskouing van die kerk as 'n communio sanctorum ${ }^{3}$ beklemtoon Barth die noodsaaklikheid van ' $n$ institusionele bestaanwyse van die kerk. Hy ag 'n definitiewe wyse van orde vir die kerklike lewe noodsaaklik. Die orde van die kerk is vir hom in die opbou van die gemeente die getuienis van die versoening in Christus teenoor die chaos en wanorde. Maar die orde van die gemeente is meer as 'n protes teen chaos. Die orde veronderstel die 'reg' wat geopenbaar is en wat tot uitdrukking kom in die onderlinge verhouding van lidmate, die ordehandhawing teenoor lidmate en in die verhouding van indiwiduele kerke teenoor mekaar. In die orde word die eenheid van die kerke bewaar en beoefen ${ }^{4}$.

4. Barth verklaar sy uitgangspunt die 'christologischekklesiologischen Begriff der Gemeinde". Reeds hierdie begrip, sê hy, veronderstel uiteraard orde en reg. Trouens, die gemeente self is 'n konsep van reg en orde: "... dann sagt man schon, indem man 'Gemeinde' sagt, auch Ordnung und Recht"'s.

5. Uit Barth se "christologies-ekklesiologiese" uitgangspunt verklaar hy die gemeente as 'n "christokratische Bruderschaft" waarin die 
'christokrasie' die beheersende is. Hierdeur word die 'broederskap' as 'n regsgemeenskap gekenmerk, dit wil sê as 'n regsgemeenskap wat deur die reg van Jesus Christus bepaal word ${ }^{6}$.

6. Hierdie regsgemeenskap veronderstel hoegenaamd nie juristery en burokrasie, formalisering en vertegnisering as sy reg en orde nie. Volgens Barth is reg en orde sonder Jesus Christus blote juristery en burokrasie?.

7. As die primêr handelende Subjek bepaal Jesus Christus self die orde en die struktuur van die gemeente in 'n unieke onderskeid met elke ander samelewingskring. Trouens, Christus is self die lewende wet waarin die gemeente lewe. Derhalwe is kerkreg ook 'n ander reg, as enige ander vorm van die reg. . Kerkreg is 'n "geestelike reg' wat deur die Heilige Skrif bepaal word. Só is die kerkreg belydende reg. Deur na die bepalinge vir die kerk in die Ou en die Nuwe Testament te luister, is die Skrif (self norma normata!) norma normans in sy betrokkenheid by ware kerkreg. Belydende kerkreg moet derhalwe in die praktyk die belydenis van die reg van Jesus Christus wees, soos in die Skrif bekend gemaak'

8. 'n Belangrike punt wat Barth stel, is dat die wêreld 'n totaal verskillende konsep van die gemeente sal hê, as wat die gemeente van homself het. Uit die wêreldlike oogpunt sal die kerk na nóg 'n sosiologiese konstruksie lyk. Die kerk moet egter daarteen waak om homself in terme van die wêreld se misverstand te beskou. Hierin lê die wortel van baie kerkregtelike misvattinge ${ }^{10}$.

9. Vanweë die wêreld se beskouing van die kerk, teenoor die kerk se beskouing van homself, maak Barth 'n onderskeid tussen 'staatskerkreg' en 'kerkreg'. Kerkreg, wat uit die "Grundrecht" van die gemeente ontplooi word, is geldend vir die gemeente onafhanklik van alle staatskerkreg en sonder beinvloeding van staatsinstansies (bv. wat die kerkorde betref) - alleen in gehoorsaamheid aan die Here as die Hoof van sy liggaam. Die kerk kan egter ook nie, ten spyte van sy unieke aard, ontken dat dit 'n mensgemeenskap is, wat soos die ander samelewingskringe juridies gesproke onder die jurisdiksie van die staat val nie"

10. ' $n$ Waardevolle perspektief by Barth is dat kerkreg wesenlik ' $n$ "Dienstrecht" is. Die gemeente van Christus, as die liggaam waarvan Hy die Hoof is, bestaan in diens tot Hom en aan mekaar onderling. Die beslissende basis van kerkreg lê in die feit dat die Here self gekom het "nie om gedien te word nie, maar om te dien" (Mk 10: $45)$. In sy diens regeer Hy. Die beginsel van 'n diensreg is vir Barth totaal en universeel: daar is geen sfeer in die kerklike lewe waarin dié beginsel nie geld nie, tot selfs die kerkadministrasie waaronder veral finansiële sake ${ }^{12}$.

My kritiek teen Barth se beskouing van kerkreg as 'n "diensreg" is egter dat hy nie onderskeid tussen 'diens' en 'bediening' maak nie. Dit lei daartoe dat daar weinig sprake van kerkregering in Barth se teologie te vinde is, ${ }^{13}$, teenoor die beskouing dat kerkreg ' $n$ bedieningswetenskap is, diensbaar aan die kerkregering wat as 'n Christusregering fungeer ${ }^{14}$. 
11. Barth oordeel dat kerkreg 'n 'liturgiese reg' is ${ }^{15}$. Hy sê dat kerkreg oorspronklik gesoek en ontdek en geken is in die erediens. Die erediens is volgens hom die konkrete bron van ons kennis van kerkreg, omdat Christus in die erediens teenwoordig is en Hy is immers die lewende wet van die kerk. So kom ons weer by die Heilige Skrif as die diepste grond van die kerkreg uit ${ }^{16}$. Die kerkreg het ten doel om sy eie grond en sy eie bron te beveilig ${ }^{17}$.

12. Vir Barth is kerkreg lewende, dinamiese en bewegende reg. Deurdat dit direk af te lei is uit die "Grundrecht" van die gemeente (die verhouding van Hoof en liggaam), is dit die Here self wat in elke situasie beslis wat vir sy kerk reg en verkeerd is. Derhalwe kan kerkreg nie deur die tydsgees, deur politieke en sosiale veranderinge en deur rewolusies in die wêreld beweeg word nie. Maar dit is die Heilige Gees wat kerkreg in beweging hou. Omdat die kerkreg lewende reg is, vereis dit deurentyd herondersoek deur die gemeente om steeds nuwe antwoorde te gee $^{18}$.

13. Omdat kerkreg ontdek en geken moet word ${ }^{19}$, is dit ongetwyfeld ius humanum (menslike reg) en nie ius divinum (goddelike reg) $\mathrm{nie}^{20}$.

14. Ware kerkreg is vir Barth ook voorbeeld-reg: vanweë die aard en die ontplooiing van kerkreg is dit 'n voorbeeld vir die uitbouing van menslike reg op elke terrein. Kerkreg het nie slegs met sy "eie saak" te maak nie. Dit beteken egter nie dat kerkreg ook staatlike reg én verenigingsreg moet wees nie. Maar die kerkreg se voorbeeld vir elke ander reg lê daarin dat dit die evangelie bekendmaak, want wat die kerk die wêreld skuld is nie 'n wet of 'n ideaal nie, maar die blye boodskap van verlossing in Jesus Christus ${ }^{21}$.

\section{Slot}

My slot by Karl Barth se verbasende kerkregbeskouing is 'n nadenkende vraag: Sou die Duitse kerkreg wat steeds (ná Sohm) met die vraagstuk van 'n tweespalt tussen kerk en reg worstel ${ }^{22}$, nie lankal uit hulle dilemma gewees het indien hulle Karl Barth se kerkregsbeskouing ernstig opgeneem het nie?

\section{Aantekeninge}

1. Karl Barth, 1855. KD, IV,2 : 768 .

2. Idem : 770 .

3. Bv. idem : 765. Barth se kerkbegrip is duidellk kongregasionalisties. Dit blyk ook uit sy "Die Schrift und die Kirche", nr 22 in "Theologische Studien".

4. Idem : 767. Barth verskil van Rudolph Sohm, en Emil Brunner na hom (vgl. idem:769,770v, 774v), in hulle siening van die kerk as 'n geestelike en vrywilige gemeenskap (vgl. Sohm, 1892: Kirchenrecht, dl. I : 23 en Brunner, 1939: Das Gebot und die Ordnungen : 194, 318) : "Was Brunner 'Christusgemeinde' nennt, ist sachlich nichts Anderes als das, was bei Sohm 'Geistkirche', Liebeskirche" usw. heist". En, baie belangrik: "Christus ist auch bei ihm (Brunner - CJS) Prädikat der christlichen Gemeinschaft und nicht umgekehrt (Barth, idem : 769).

5. Idem: 770. Merkwaardig hoe Barth in hierdie siening met Calvyn oor- 
eenstem (of by hom aansluit?) (Vgl. o.a. oor Calvyn B. Spoelstra, 1978 : Calvyn en die grense van die kerk, In die Skriflig. 12(45):20-35, Mrt., p 27v en B. C. Milner, 1970 : Calvin's doctrine of the church, p44).

6. Barth sluit aan by Erik Wolf wat die gemeente sien as "die Gemeinde des Herrn und der von ihm Erwählten, die so zu Brüdern gemacht sind". Hiervolgens is die kerk ' $n$ "bruderschaftliche Christokratie". (Wolf, 1952 : Zur Rechtsgestalt der Kirche in "Bekennende Kirche", p 254vv, 261).

Teenoor Sohm en Brunner stel Barth dat beide die begrip 'Christokrasie' nie verdiskonteer nie, daarom kom hulle nie by die "Grundrecht" uit, waardeur die kerk kerk is, nie (KD, IV, 2:770v). En dáárom is die kerkreg vir beide oorbodig (vgl. Sohm, idem : 459 en Brunner, 1951 Das Missverständnis der Kirche : 97). Sohm oordeel bv. dat kerkreg die werk van kleingelowiges is en volgens Brunner is kerkreg 'n substituut vir 'n vermissing van die Heilige Gees!

7. Barth, idem: 771. Saam met Erik Wolf (idem : 254vv) bevind Barth hom weer verrassend na-aan Calvyn. Juis omdat Sohm en Brunner die christologies-ekklesiologiese grondreg van die kerk ignoreer, ontkom hulle volgens Barth nle die gevaar van juristery en burokrasie nie (ibid).

8. Barth, idem: 771v: "Rechtes Kirchenrecht entsteht (in grossen und kleinen, in allen Dingen!, aus dem Hören auf die Stimme Jesu Christi".

9. Barth, idem : 772-774. Barth sluit hier geheel en al by Erik Wolf se "bekennendes Recht" aan.

10. Idem : $777 \mathrm{v}$.

11. Idem : 778-781. Die ius circa sacra wat Barth bepleit, kom in 'n sekere sin neer op die gemeenregielike regspersoon wat netjies deur G. Pienaar uitgewerk is in sy proefskrif: Die gemeenregtelike regspersoon in die Suid-Afrikaanse Privaatreg, $1982: 298 \mathrm{vv}$, waarvolgens kerke t.a.v. die staatlike reg op grond van 'n interne verbandsreg (idem : 275v) ook aan die regsverkeer kan deelneem en waar nodig deur die staatlike reg beoordeel kan word.

12. Barth, idem : 781vv.

13. Vgl. ook G. C. van Niftrik se ietwat verouderde, 1948 : Een beroerder Israels : $218 v$.

14. Die kerkreg in sy bedieningsfunksie is in my proefskrif uitgewerk as 'n beskouing waardeur geen menslike wette deur kerkvergaderings gepositiveer word nie, maar waarin God se Woord in die kerkregering aan die orde gestel word: Kerkreg en kerkorde in die lig van God se reg en orde vir sy kerk, 1985 : 285vv.

15. Barth, idem : 787vv.

16. Vgl. die ooreenkoms met Martin Bucer wat geoordeel het dat die kerkreg sy beslag in die eenheid van Woordbediening en die werksaamheid van die Heilige Gees kry (W. van 't Spijker, 1972 : Goddelijke recht en kerkelijke orde by Martin Bucer: $p$ 12vv).

17. Vgl. C. J. Smit, 1985: Kerkreg en kerkorde in die lig van God se reg en orde vir sy kerk, p 283-306, veral op p 299 waar 'n kerkregbeskouing as bediening van die herstelling in Jesus Christus (in die wydste betekenis van dié begrip), en ter beveiliging daarvan, uitgewerk is.

18. Barth, idem : 805v. Vgl. Smit, idem: p 292vv en 299vv waar kerkreg as 'n herstellingsreg mér as formele reg geag word en ook mér as institusionelie reg.

19. Barth, idem : 800 .

20. Barth, idem : 808 .

21. Barth, idem : 815-817. Ook Erik Wolf, na wie Barth verwys, het gese: Wat kon dit nie vir die wereld beteken het as kerkreg nie bloot as 'n "positiwisties-juristiese reg gesien is nie, maar as 'n belydende reg, 'n lewende gemeente-ordening wat vir alle mense 'n getuienis is van die Hoof van hierdie gemeente : Christus!". (E. Wolf, 1948 : Rechtsgedanke und biblische Weisung, $p$ 93). G. P. L. van der Linde het aan dieselfde gedagte gewerk in sy klasdiktaat, 1980/81, Kerkreg $1: 20 \mathrm{vv.}$

22. Vgl. hierdie teologiese worsteling vanaf Sohm aan die begin van die eeu, en die pogings tot 'n teologiese versoening tussen kerk en reg vanaf die dertigerjare, veral ná die Tweede Wereldoorlog in Smit, idem: 263vv, veral $269 \mathrm{vv}$. 